\title{
THE CORRELATION STUDY ABOUT POSITIVE THINKING AND BEHAVIOR FORGIVENESS AMONGS STUDENTS
}

\author{
Oleh: \\ Reza Fahmi, Jamaldi, Dila Fulnandra* \\ UIN Imam Bonjol Padang \\ rezafahmi@uinib.ac.id
}

\begin{abstract}
The purpose of this study was to determine the category of positive thinking, the category of forgiving behavior and to determine the relationship of positive thinking with Forgiveness Behavior in friendship at Heler boarding school students. The research method used quantitative methods with data analysis techniques, namely Pearson Correlation analysis. The population in this study amounted to 78 people with a sample of 65 people. The sampling technique used was stratified random sampling. The data collection technique used in this study was a psychological scale, which was guided by a modified Likert scale, namely a positive thinking scale and a forgiving behavior Thus $\mathrm{H}_{o}$ rejected and $\mathrm{H}_{a}$ accepted, meaning that positive thinking with a forgiving behavior in friendship at the boarding students heler in Lubuk Leeches have a positive and significant relationship.
\end{abstract}

Keywords : Positive Thinking, Forgiveness Behavior, Students, and Human Relations.

\section{A. INTRODUCTION}

Humans are known as social creatures, where in the process of human development cannot be separated from social interactions. In interacting socially, of course, it does not always run smoothly, such as quarrels, conflicts or making mistakes with others that make other people hurt. It's really bad if someone has done something wrong, moreover not apologizing. But sometimes there are also many people who have apologized to someone but cannot be forgiven. Or sometimes the person being apologized has forgiven but the person is not sincere in his heart.

Forgiveness is the key word to open the door to revenge and the shackles of hatred for someone. Sorry 
can also cause a person to break the attachment to selfishness.

Forgiveness (in Hasan, 2013: 13-14) is socially used as an instrument to prevent someone's desire to take revenge. McCulloug (in Anggraini and Hijriyati, 2014: 19) argues that forgiveness can be used as a set of motivations to change someone not to take revenge and reduce the urge to maintain hatred against the hurting party and increase the urge to conciliate the relationship with the offending party. A similar opinion is expressed by Wardhati and Faturochman (2006: 3) explaining that forgiveness is a willingness to put off painful mistakes of the past, no longer look for value in anger and hatred, and ward off the desire to hurt others or yourself.

As human beings, of course, we have experienced ups and downs in relationships, for example, friendship. In friendly relations, forgiveness (in Utami, 2015: 56) is what individuals who make mistakes want and need. Forgiveness means removing wounds or scars in the heart, according to Shihab, in forgiveness there is a readiness to give forgiveness / forgiveness to others, whether asked for or not asked for.

Price, Ladd and Hays (in Anggraini and Hijriyati, 2014: 20) define friendship as a relationship in which certain social and emotional needs are met, such as emotional support, task assistance, intellectual stimulation. According to Hajad (2011: 343) friendship means friendship, and he will not last long without the willingness to forgive his friends' mistakes, friends or friends must be treated in ways they like so that friendship or friendship does not break up and maintains love for friends. The old brothers who are in the faith are an indicator of the greatness of one's behavior and the way to gain the trust of others.

Some of us even receive hurtful treatment from the people we love the most and some are living in an environment that constantly suppresses and belittles their dignity.

That's why it can be felt by anyone, one of them is a student. Some of these students live in groups (dormitories) and some live individually (boarding houses). Where the boarding house is a temporary residence other than the house in the village yard. In a boarding house, someone has many friends or friends because generally a student boarding house accepts several people who will live in the boarding house. Therefore, a person must be able to adapt to his environment. In self-adjustment, of course, it doesn't always run smoothly, there are often problems and mistakes that make the hearts of the boarding house residents hurt. Some problems can be resolved completely and some are not resolved or in other words there is no word of peace between the two troubled parties. 
Researchers focus more on this research on students who live in a boarding house Heler. Kos Heler is one of the boarding houses under the leeches, where most or it can be said that all residents are students of UIN Imam Bonjol. UIN Imam Bonjol students are students who are required to be able to master and live up to the main teachings of Islam, namely Alqur' an and Hadith. By learning the pillars and principles of Islam, it is hoped that students will adapt their behavior to the guidance taught by the sources of Islamic teachings. But the fact that happened to UIN students who live in Heler's boarding house, it turns out that the behavior of forgiveness is not all the residents there can practice it.

One of the factors that can develop self-forgiveness behavior is the ability to think positively. Positive thinking makes a big difference in the life of every individual, because a good attitude starts with positive thinking.

Makin \& Lindley (in Nurmayasari and Hadjam, 2015: 9) say that positive thinking is a way that can make someone more positive, namely by reassessing everything by looking at its positive aspects. Positive thinking will produce a positive mental attitude that will help individuals build hope and overcome discouragement and discouragement.

Based on the above, the problem in this research is whether thereis than association berpikir positif dith behavior forgive in a friendly on heler boarding student at the bottom of a leech. The aim of the study was to determine the category of positive thinking, behavior categories forgive and toknow association bepikir positif dith behavior of Forgiveness in friendship to students boarding Heler Practical benefits of this research is expected to provide information on the relationship of positive thinking with behavior forgive the student for the reader. In addition, the owner of the boarding house should pay attention to and follow the developments or problems of the boarding house students in order to create harmony between fellow boarders.

\section{B. THEORITICAL BACKGROUND}

\section{Positive Thinking}

Positive thinking is the ability, activity or way of thinking that is carried out by a person with the aim of developing and developing aspects of thinking objectively, rationally and ssessing something from the side of good so that it creates calm and happiness in living life. Positive thinking emphasizes a way of thinking, a positive point of view and emotions, both towards yourself, other people and the situation at hand. Positive thinking is a source of strength that can help someone think of solutions until they get it so that someone becomes more proficient, trusting and strong. Positive 
thinking is also a source of freedom because it can free someone from the confines of negative thoughts and their effects on the physical.

Here are some definitions of positive thinking from several book sources:

- According to Andrea (2011), positive thinking is a mental attitude that involves the process of entering thoughts, words and images that are constructive for the development of the mind. Thus, positive thoughts will give birth to happiness, joy, health, and success in every situation and action.

- According to Arifin (2011: 18), positive thinking is a thinking activity that we do with the aim of building and arousing positive aspects of ourselves, both in the form of potential, enthusiasm, determination and our selfconfidence.

- According to Vincent (2006: 135), positive thinking is the ability to think of a person to assess experiences in his life, as valuable material for subsequent experiences and consider them as a life process that must be accepted.

- According to Saleh (2012: 157), positive thinking is a thought that directs a person to see things positively or in a positive way

\section{Positive Thinking Aspects}

According to Albrecht (1992), there are four aspects of positive thinking, namely as follows: a. Positive expectations. When individuals have problems, the positive aspects of hope will direct their minds to do something by focusing more on success, optimism, problem solving, distance themselves from feelings of fear of failure, and increasing the use of words that contain hope.

b. Self affirmation (self affirmation). With this aspect of self-affirmation, when a person gets into a problem, he will focus more on selfstrength, self-confidence and see himself positively on the premise that each individual is as meaningful as others.

c. Statements that do not judge (non judgment talking). A statement that describes the situation more than judging the situation and is not fanatical in opinion. This nonassessing statement is intended as a substitute for when someone tends to give a negative statement or judgment. This aspect will play a big role when someone is facing a situation that tends to be negative.

d. Realistic adaptation (reality adaptation). With this realistic aspect of adjustment, someone who is facing problems will try to adjust to the reality that is happening. He will accept problems and try to deal with them, keeping himself away from regret, frustration and self-blame. 


\section{Positive Thinking Indicators and Traits}

According to Asmani (2009: 26), there are several indicators of someone who thinks positively, namely as follows:

a. Be confident. When a person has positive thoughts, he will believe in himself and in others. Thanks to positive thinking a person becomes more willing to try new things and try various opportunities.

b. Initiative. Self-confidence also makes someone a person who is full of initiative. The belief that life is positive can generate a strong inner desire to try new things.

c. Persistence. If someone believes that positive things will happen then that person will keep on trying until the positive things actually appear. Even if there are various obstacles, we will still not back down.

d. Creativity. If a person's mind is focused on positive things, there will be a great desire in that person to continue to investigate, ask, and look for new challenges.

e. Leadership. Learning to become a great leader is a long process, but it can be started from relationships with other people. People won't want to follow someone they don't like, even if they don't for a long time. And it's rare to find people who genuinely like negative people.

f. Development. If we think positively many doors are wide open for us. One of the most important is the door of opportunity to grow and develop. A good attitude will make you thirst for development.

g. The ability to produce something. Nothing can stop the Yan people

\section{Forgiveness Theory}

Forgiveness in Indonesian comes from the root word sorry and the affix "pe-an". According to the Big Indonesian Dictionary Compilation Team (2012), forgiveness means the release of someone from punishment (demands, fines, etc.) because of an error. While forgiveness can be interpreted as giving forgiveness for mistakes and so on, do not think wrong anymore. 6 Whereas in English, the word forgiveness means the word forgiveness. Forgiveness comes from the word forgive and the affix ness. Oxford Advanced Learner's Dictionary of Current English defines forgive as forgiveness or showing kindness to someone (pardon or show mercy to somebody) -, not maintaining feelings of displeasure towards someone (no longer have hard feeling towards). In this regard, Nashori offers a suggestion to improve the translation of the word forgiveness in the Big Indonesian 
Dictionary. He gives two notes on the translation: 1) The meaning of forgiveness in Indonesian tends to be interpersonal or social. The notion of forgiveness in Arabic and English tends to be intrapersonal with interpersonal goals. The conclusion that can be made, forgiveness is to erase the hurt and its effects such as lawsuits, and so on; 2) It seems that the meaning of forgiveness in the Big Indonesian Dictionary needs to be improved because it limits forgiveness to only "exemption from punishment". Forgiveness should be given a broader meaning, including kindness to the offender. The word forgiveness also has a close relationship with the field of psychology. In contrast to linguists, psychologists provide a relatively broader understanding of forgiveness. By psychologists, forgiveness of someone is distinguished from excusing (liberating) which does not acknowledge injustice, reconciling (reconciling) which involves mutual trust of both parties, and forgetting (forgetting) which is not really

liberate.

Robert D. Enright, one of the psychologists states that forgiveness is a person's willingness to leave anger, negative judgments, and behavior indifferent to others who have hurt him unfairly. Removing and forgetting the evil behavior of others is an important element of forgiveness. As described by Nashori, that forgiveness is to remove a wound or scars in the heart. It may be that the memory of the event that was heartbreaking in the past still exists, but the perception of the incident that was heartbreaking has been erased. Thompson defines forgiveness as an effort to place the perceived violation in such a way that a person's response to the perpetrator, events, and the consequences of the events experienced is changed from negative to neutral or positive. In line with this, Walrond-Skinner concluded with theoretical considerations that forgiveness acts as a reframe because it allows a person to see and experience (treat) painful past events in a different light. Forgiveness is also a temporary empowerment agent because it changes the balance of power in a relationship. Usually, power lies with the offender (perpetrator). In addition, forgiveness acts paradoxically to release (defuse) the conflict of two parties because it removes much of the confusion that arises with feelings of ambivalence around the offense.

McCullough, Worthington, \& Rachal define forgiveness as the reduction of change that is motivational for revenge and motivation to avoid people who have hurt, which tends to prevent destructive responses in social relationships and encourages someone to show constructive behavior towards those who have hurt them. On another occasion, McCullough said that forgiveness is a series of motivational / behavioral changes by reducing the motivation to take revenge, abstaining from or avoiding violent behavior and 
increasing motivation or desire to make peace with the perpetrator. the main elements, namely: eliminating and forgetting all feelings of pain and injustice caused by the actions of others because of the motivation to build better relationships. This is as Gustafson describes forgiveness into five points, namely; deciding, punishing, perceiving an injustice, taking action, experiecing emotional relief. The five points are taken from the meaning he made, namely: "Forgiveness means deciding not to punish a perceived injustice, taking action on the decision, and experiencing the emotional relief that follows.

\section{Islamic Values of Forgiveness}

Furthermore, several verses in the Qur'an are not found a single verse that recommends apologizing, however there is an order to forgive, like the letter Ali-Imran: 152 and 155; Surat alMaidah: 95 and 101. Likewise, that was suggested by a verse that suggests not waiting for petition sorry from the guilty, but should forgive before being asked. Those who are reluctant to apologize to essentially reluctant to obtain fo giveness and Allah (al-Nur:

Likewise during the Hajj Wada 'event, the prophet was getting more and more clarify and reinforce the fundamental principles on equality, reconciliation, and forgiveness between all the Ummah through khutbah wada'nya. While at the events in Taif and Fathu Makkah, it has been proven a prophet's sincerity not to return anything which they (the inhabitants of Makkah and Taif) did, but rather high motivation to forgive them.18 Demonstration of high

Moral in Islam has also been shown by Abu Bakr when forgive Mistah, one of the people who slandered Siti 'Aisyah. He forgave it even though Mistah could be threatened with punishment heavy ones.

Forgiveness is one of the principles of applying inner qisas sanctions Islam. That in the fingers of murder, a murderer has cut ties with a person or a people. With do qisas, then the break of this relationship continues. Therefore The remedy for this situation is only one forgiveness. With forgiveness, the relationship between the two becomes nourished, his affection becomes re-awakened (renewed), the ugliness between the two becomes lost. It is on this basis that God loves forgiveness of perpetrators of crimes, as instructed in the al-Qur'an (QS. 2: 178).

\section{RESEARCH METHODOLOGY}

Metode research

is quantitative, scientific method which has met the scientific principles concrete / empirical, objective, measurable, rational and systematic ( Sugiyono, 2010: 7). The independent variable of this study is positive thinking, while the dependent 
variable is forgiveness. The sampling technique used was stratified random sampling, that is, taking the number of samples for each group in the study adjusted to the size of the population in that group. To simplify and present sample data, it is distributed into the following table:

\section{Number of Research Samples}

\begin{tabular}{|c|c|c|c|}
\hline No. & Force & Sample & amount \\
\hline 1 & 2013 & $\begin{array}{l}\text { Sample } \\
\times 65=3\end{array}$ & 3 people \\
\hline 2 & 2014 & $\begin{array}{l}\text { Sample } \\
\times 65=12\end{array}=$ & 12 people \\
\hline 3 & 2015 & $\begin{array}{l}\text { Sample } \\
\text { x } 65=15\end{array}=$ & 15 people \\
\hline 4 & 2016 & $\begin{array}{l}\text { Sample } \\
\times 65=9\end{array}$ & 9 people \\
\hline 5 & 2017 & $\begin{array}{l}\text { Sample }= \\
\times 65=8\end{array}$ & 8 people \\
\hline 6 & 2018 & $\begin{array}{l}\text { Sample }= \\
\times 65=18\end{array}$ & 18 people \\
\hline & & bunt & \\
\hline
\end{tabular}

The population of this study were students of the Imam Bonjol State Islamic University in Padang, including residents of the Heler boarding house with a total of 78 students. and a sample of 65 people taken randomly through the Slovin formula.
The type of scale used in the study is an ordinal scale with a Likert scale, because it is in accordance with the research objectives to measure the attitude of the subject regarding the variables studied. 


\section{Positive Thinking Scale Reliability Test Results}

Reliability Statistics

\begin{tabular}{|r|r|}
\hline $\begin{array}{c}\text { Cronbach's } \\
\text { Alpha }\end{array}$ & N of Items \\
\hline .937 & 80 \\
\hline
\end{tabular}

Source: Trial Results

\section{Forgiveness Behavior Reliability Test Results}

Reliability Statistics

\begin{tabular}{|r|r|}
\hline $\begin{array}{c}\text { Cronbach's } \\
\text { Alpha }\end{array}$ & N of Items \\
\hline .946 & 41 \\
\hline
\end{tabular}

Source: Trial Results

According to Sekaran (in Priyatno, 2012: 187), reliability that is less than 0.6 is not good, while 0.7 is acceptable, and above 0.8 is good. So, from the above explanation the writer takes the reliability limit of 0.8 .

The implementation of data collection in this study used two scales, namely a scale consisting of 80 statement items and a scale of forgiveness behavior consisting of 41 statement items. On each scale, there is an identity sheet, an answer column, and how to fill in and say thanks. Apart from that, the authors used interviews and observations as initial data collection.

\section{RESULT AND DISCUSSION}

Description of research data is used to create variable categorization by classifying subjects into two categories, namely high and low. According to Azwar (2005), the scale score as a result of measuring in the form of numbers (quantitative), the score requires a norm of comparison so that it can be interpreted qualitatively. Based on these objectives, the researcher determined a categorization according to the following formula. 
Positive Thinking Categorization Formulas

\begin{tabular}{cc}
\hline Formula & Categorization \\
\hline $\mathrm{x}<(\mu-1,0 \sigma)$ & Low Category \\
\hline$(\mu+1,0 \sigma) \leq \mathrm{x}$ & High Category \\
\hline Note: $\mu=$ ideal mean, $\sigma=$ standard deviation
\end{tabular}

The category formula above is student boarding house under the used as a reference to determine the leech. Categorization based on the positive thinking category and the results of this study can be described in category of forgiving behavior in the the following table.

\section{Positive Thinking Scale Categorization}

\begin{tabular}{ccccc}
\hline No. & Score & amount & Category & Percentage \\
\hline 1 & $160-201$ & 35 & Low & $54 \%$ \\
2 & $202-242$ & 30 & High & $46 \%$ \\
\hline \multicolumn{4}{l}{ Source: } & Research Data
\end{tabular}

Based on the analysis of the data obtained, it shows that the data obtained was also seen from the 65 subjects studied, as many as 35 people or $54 \%$ had a low level of positive thinking, and 30 people or $46 \%$ had a high level of positive thinking. This indicates that most of the boarding house students in Lubuk Lintah are more dominant in having a low level of positive thinking.

A student is said to have a low level of positive thinking when he tends to think negatively which makes it difficult for someone to accept other people's opinions, difficult to accept new things and difficult to socialize. If the negative side is more dominant in 
someone's mind, it will be filled with prejudice, blame themselves and others, pessimism, mistrust and suspicion which are often without foundation or no reason at all. As stated by Rahardian Sukma (2017: 26), negative thoughts are a collection of wrong thoughts that hinder one's steps to get better conditions and situations and make human behavior unfocused. In its form, these negative thoughts are not only in forms such as anger, jealousy, or prejudice. $\mathrm{P}$ ikiran negative can also be anxious, scared, sad, anxious, restless, frustrated, feeling lonely, feeling worthless, pessimistic and easily give up .

\section{Forgiveness Behavior Scale Categorization}

\begin{tabular}{ccccc}
\hline No. & Score & amount & Category & Percentage \\
\hline 1 & $87-118$ & 41 & Low & $63 \%$ \\
2 & $119-149$ & 24 & High & $37 \%$ \\
\hline
\end{tabular}

Source: Data Advanced Research $n$

Based on the analysis of the data obtained, it shows that the data obtained also shows that from the 65 subjects studied, 41 people or $63 \%$ had a low level of forgiving behavior, 24 people or $37 \%$ had a high level of forgiving behavior. This indicates that most of the boarding house students in Lubuk Leech are more dominant in having a low level of forgiving behavior.

A student is said to have low forgiveness behavior when he tends to find it difficult to forgive others because there is still a feeling of resentment and anger in his heart which is due to the conflict that happened previously in a person. One of the conflicts that often occurs is conflict with a roommate in which friendship in one room must feel a conflict. Examples of things that cause conflicts are the existence of a picket schedule that is not carried out according to what has been jointly determined, assuming that his friend's items are his own in the broad sense of being free to use his friend's goods or food, feeling jealous and being ostracized because his friend is too close to other friends, offended by the way Talking to friends who are not suitable, accounts payable that have not been paid, are not suitable for his learning habits in a broad sense, he can 
learn when there is no sound and his friends like to learn using music and in terms of room conditions, namely when one likes tidiness and cleanliness but his friend always make the room messy and dirty. As stated by Baumeister (in Sumiati and Stefanus, 2013: 147), one of the obstacles to forgiveness is the inability of the individual to see the potential that exists within him to do something that should not be done to other individuals. Baumeister further explained that the inability to understand that an individual might commit mistakes by other individuals is related to harsher (immature) judgment and low readiness to forgive.

Through the results of research data processing, the author can conclude that there is a positive thinking relationship with forgiving behavior. This can be proven based on the results of data analysis that has been carried out, namely:

\section{Linearity Test}

The inearity test aims to determine whether the two research variables have a significant linear relationship or not. Both variables are said to be linear if they have a small significance level of 0.05 (P $<0.05$ ) (Priyatno, 2014: 79).

\section{Normality Test of Positive Thinking Scale Distribution and Forgiveness Behavior}

Based on the linearity test in SPSS version 16.0 for windows, it can be seen that the significance value for linearity is 0.000 and the $\mathrm{F}$ value $=63,906$, because the significance is smaller than 0.05 $(0.000<0.05)$, it can be concluded that there is a linear relationship between positive thinking and forgiveness behavior, so the assumption of linearity is fulfilled.

\section{Normality Test}

The normality test aims to determine whether the data population is normally distributed or not. Normal data distribution states that the research subject is representative or can represent the existing population, preferably if the distribution is not normal, it can be concluded that the subject is not representative or does not represent the existing population. The normality test in this study used the Kalmogorov Smirnov one sample test, it can be stated that it is normally distributed if the significance is greater than 0.05 (Priyatno, 2012). Based on data processing using SPSS version 16.0 for windows , the normality test results are obtained as follows.

\section{Behavior}

$\begin{array}{lll}\text { Variable } \quad \text { Kolmogorov-Smirnov Z Asymp Sig } & \text { Asmo }\end{array}$




\begin{tabular}{lcc}
\hline Positive thinking & 0,769 & 0,596 \\
\hline Forgiving Behavior & 0,766 & 0,601
\end{tabular}

Source: SPSS 16.0 data for windows

To find out whether the data is normally distributed or not, it can be seen from the One-Sample Kolmogorov Smirnov Test table in the table above. The test criterion is if the significance value is> 0.05 then the data is normally distributed. From table 4.5 above, it can be seen that the significance value (2-tailed Asymptotic Significance) for positive thinking is 0.596 and forgiveness behavior is 0.601 . The significance for positive thinking variables is greater than 0.05 , then it is normally distributed and for the significance of forgiving behavior is also greater than 0.05 , then it is normally distributed. So, it can be concluded that the data on the positive thinking scale is normally distributed and the data on the scale of forgiveness behavior is also normally distributed.

3. Hypothesis testing

Hypothesis testing is
carried
using Pearson correlation statistical analysis to determine whether or not there is a positive thinking relationship with forgiveness behavior. Based on the results of calculations using the SPSS version 16.0 for windows program, it is obtained as follows:

\section{Hypothesis Test for Positive Thinking Scale Distribution} and the Forgiveness Behavior Scale

\begin{tabular}{ccc}
\hline Variable & Pearson Correlation & Sig \\
\hline $\begin{array}{l}\text { Positive Thinking - } \\
\text { Forgiving Behavior }\end{array}$ & 0,666 & 0,000 \\
\hline Source: SPSS 16.0 for windows & &
\end{tabular}


The results of the analysis in the table show that the value of the Pearson correlation coefficient is positive thinking with forgiveness behavior of 0.666 . If the significance value $<0.05$ means that the hypothesis is accepted, whereas if the significance value> 0.05 means the hypothesis is rejected (Prayitno, 2012: 109). The significance value of positive thinking and forgiving behavior is $0.000(0,000<0.05)$ so $\mathrm{Ha}$ is accepted. This means that at the significance level between the two variables, it shows a relationship between positive thinking and forgiving behavior. It can be concluded that there is a relationship between Positive Thinking and Forgiving Behavior in Friendship among Students at Kos Heler in Lubuk Lintah. This means that the

\section{Daftar Kepustakaan}

Angraini, Dewi and Hijriyati Cucuani. Relationship Quality Friendship And Empathy On Late Adolescent Forgiveness . Riau: State Islamic University of Sultan Syarif Kasim, Riau. Journal of Psychology, Vol. 10. No. 1.

Azwar, S. 2009. Compilation of the Psychological Scale Yogyakarta. Student Libraries.

Hajjad, Muhammad Fauqi. 2011. Islamic Sufism and Morals . Jakarta: Amzah. higher or lower the level of positive thinking of students will affect the level of forgiving behavior.

\section{E. CONCLUSION}

Based on the above, it can be concluded that the Supreme students boarding heler in Lubuk Leeches have a low level of positive thinking and behavior that condone low. Hypothesis testing shows that there is a relationship between Positive Thinking and Forgiving Behavior in Friendship among Students of Kos Heler in Lubuk Lintah or Ha is accepted. This means that the higher the level of positive thinking in boarding school students, the higher the behavior of forgiveness. Conversely, the lower the level of positive thinking in boarding school students, the lower the behavior offorgiveness

Hasan, Aliah B. Purwakania. 2013. Forgiveness as a Moderator Variable on the Effect of Religiosity with Relational Aggression among University Students Based on Islamic Values . Jakarta: Al Azhar University Indonesia. Journal of Al-Azhar Indonesia Humanities Series, Vol. 2. No. 1.

Utami, Deassy Arifianti. 2015. Interpersonal Trust With Forgiveness In Friendly Relationships Muhammadiyah University of 
Malang. JipT. Vol. 03. No. 01

Mc Cullough, ME 2000. Forgivennes As Human Strength: Theory, Measurement, And Links To Well-Being. Journal of social and clinical psychology. Vol 19, No. 1

Nurmayasari, Kiki and Hadjam, Murusdi. 2015. The Relationship Between Positive Thinking And Cheating Behavior In Class X Students Of Yogyakarta Cooperative High School. Yogyakarta: Ahmad Dahlan University Yogyakarta. Journal of the Faculty of Psychology, Vol. 3. No. 1.

Priyatno, Duwi. 2012. Quick Way to Learn Data Analysis with SPSS 20 .. Yogyakarta: Andi.
Sugiyono. 2011. Quantitative, qualitative and R\&D research methods . Bandung: Alfabeta.

Sukma, Rahardian. 2017. Move on from Negative Thoughts. Yogyakarta: Serambi Semesta Distribution.

Sumiati, Ilsan and Stefanus Soejanto Sandjaja. 2013. The Relationship Between Forgiveness With SelfMaturity In Late Adolescence - Krida Wacana Christian University. Journal of NOETIC Psychology. Vol. 3. No. 2.

Authority, Lutfi. 2007. Positive Thinking Training for Out of School Adolescents Yogyakarta State University. Journal of Out-of-School Education. Vol 6, No 11. 